Yeli Nurhamsih, Syahrial

\title{
Evaluation of English Teaching Materials used at a Vocational High School Based on Cunningsworth's Checklist
}

(Bahasa Inggris Kelas XI SMA/MA/SMK/MAK, published by Kementerian Pendidikan dan Kebudayaan Republik Indonesia, revised edition in 2017)

\author{
Yeli Nuhamsih \\ Syahrial \\ Postgraduate English Program, Faculty of Teacher Training and Education, \\ University of Bengkulu \\ Email : yeli.nurhamsih@yahoo.co.id
}

\begin{abstract}
English teaching material is really important, that is why a teacher should be able to select the right book to use on teaching and learning process. One of the ways is by evaluating the textbook. This study aims to evaluate the English teaching materials covering its language content, language skills, and topics, used at a Vocational High School based on Cunningsworth's checklist. The data were taken by distributing checklist and conducting interview to one vice- principal who is also as a teacher of English and two English teachers at a Vocational High School. The data were analyzed by getting average and percentage. The methodology of the research is descriptive qualitative content analysis. Results showed that language content in the textbook viewed from criteria of good English teaching materials are poor. The textbook only covers little grammar and vocabulary. The language skills practiced in the textbook according to criteria of good English teaching materials are poor for they are in general content and limited activities. While, according to criteria of good English teaching materials, the topics introduced in the textbook are poor too. The topics covered in the textbook are general topics. It can be concluded that English teaching materials covering language content, language skills, and topics in the textbook are not appropriate for hotel accomodation students. As suggestion, the four skills should be integrated in the topics in order to give more importance to grammar and communication skills. The topics content that relate to hospitality and tourism department specially for hotel accomodation department should be provided and added so it will be meaningful for the learners espesially the learners of hotel accomodation.
\end{abstract}

Keywords: evaluation, English teaching materials, Vocational High School, checklist

Abstrak: Guru harus mampu memilih buku yang tepat untuk digunakan dalam proses belajar mengajar. Salah satu caranya adalah dengan mengevaluasi buku tersebut. Penelitian ini bertujuan mengevaluasi materi pengajaran Bahasa Inggris meliputi konten bahasa, keterampilan bahasa, dan topik, yang digunakan di Sekolah Menengah Kejuruan (SMK) berdasarkan ceklist Cunnigsworth. Data diambil dengan mendistribusikan ceklist dan melaksanakan wawancara dengan wakil kepala sekolah yang juga merupakan guru bahasa Inggris dan dua orang guru bahasa Inggris di salah satu SMK. Data dianalisa dengan mencari rata-rata dan persentase. Metodologi penelitian ini adalah analisis konten kualitatif deskriptif. Hasil penelitian menunjukan konten bahasa yang ada di buku tersebut berdasarkan kriteria materi pengajaran bahasa Inggris yang baik adalah rendah. Buku tersebut hanya berisi sedikit grammar dan kosa kata. Keterampilan bahasa yang di praktiskan dibuku tersebut menurut kriteria materi pengajaran bahasa Inggris yang baik adalah rendah karena mereka ditampilkan dalam konten bahasa inggris umum dan kegiatannya terbatas. Menurut kriteria materi pengajaran bahasa Inggris, topik-topik yang diperkenalkan dibuku tersebut juga terkategori rendah. Topik-topik yang ada dibuku tersebut adalah topik-topik yang umum. Dapat disimpulkan bahwa materi pengajaran Bahasa Inggris meliputi konten bahasa, skill bahasa, dan topik yang ada di buku tersebut tidak cocok untuk siswa akomodasi perhotelan. Sebagai saran, keempat skill bahasa harus terintegrasi di dalam topik supaya dapat memberikan pengaruh terhadap grammar dan keterampilan 
komunikasi. Topik-topik yang berhubungan dengan kepariwisataan dan perhotelan terutama akomodasi perhotelan harus dilengkapi dan ditambah sehingga buku tersebut akan bermakna bagi para siswa terutama siswa akomodasi perhotelan.

Keywords: evaluasi, materi pengajaran Bahasa Inggris, Sekolah Menengah Kejuruan, ceklist

\section{INTRODUCTION}

Textbooks have a significant role in EFL teaching and learning by providing useful ready-made material to both teachers and students. However, inappropriate use of course books may deskill teachers and their students (Charalambous, 2011).

Sheldon (1988) suggests that textbooks do not only provide the visible heart of any ELT program, but also provide considerable advantages for both students and the teachers when they are being used in English foreign language classroom. However, many textbooks are published by national publishers that sometimes may not fulfil the teachers' and students' need. So, as teachers, we should be able to select the right book that will be used in learning and teaching process. One of the ways is by evaluating the textbook.

Textbook evaluation would involve the careful selection of materials examining whether they reflect the needs of the learners, the aims, methods and values of a specific teaching program (Cunningsworth, 1995). Through textbook evaluation, teachers know the content of the book, its strengths and weaknesses which will facilitate them to adapt it to suit the course aims, learners' needs and teachers' beliefs. Moreover, Cunningsworth (1995) and Ellis (1997) states that textbook evaluation helps teachers move beyond impressionistic assessments and it helps them to acquire useful, accurate, systematic, and contextual insights into the overall nature of textbook.

In previous curriculum, it differs the syllabus for Sekolah Menegah Atas (SMA) and Sekolah Menengah Kejuruan (SMK). It means the materials between SMA and SMK are different but in current curriculum, they have the same syllabus and the same recommended textbooks. Based on the researcher's experience in teaching English at SMKN 5 Kepahiang, many previous textbooks do not fulfil the students' need relating to their departments such as Automotive, Hotel Accommodation, Multimedia and Marketing Department. Even in current curriculum, where the syllabus between SMA and SMK are the same, it will really appear problem because it's not suitable to their programs. It's as one of English teacher's roles to incorporate and facilitate the students to retain it.

Vocational High School is a school that aims to prepare learners for careers that are based in manual or practical activities, occupation or vocation. Therefore, English for Specific purposes (ESP) is needed in teaching and learning process in order to incorporate students specific needs in enrolling the courses at SMK. ESP is designed for a particular group of people in a particular context where the materials used are related to the learners' specialized field of study.

The learners who are obligated to meet the essential, specific and precise needs to respond to the considerable demands in vocational or academic situations in English are encouraged to learn English for specific purposes (Chang, 2009; Tsao, 2011). However, the current English textbook recommended to use at SMK are the same to SMA. it is predicted that the English used in the textbook is general English.

According to Cunningsworth (1995), materials evaluation is a complex matter, for there are many variables that influence the success or failure of coursebooks when they are in use. So, according to him, in evaluating teaching materials, it is essensial to limit the number of aspects used, the number of 
question asked or statement given, to manageable proportion. That is why the researcher limited only three aspects to be evaluated namely language content, language skills, and topics. The researcher views that those aspects occurs frequently in the learning and teaching process. In other words, those are main aspects in teaching and learning process.

There have been studies on this topic such as from Tok (2010), Lee (2013), Haghi (2013), Anjaneyulu (2014), Rahmawati (2016) Salehi (2015). and Al harbi (2017). Lee (2013) stated that the analysis and the evaluation of existing textbook holds a very essential role in developing new textbooks process. She found we should arrange our own standards for the current textbooks, upon considering foreign theory's connectivity with our curriculum, the learners requirements and our unique cultural background all together.

Anjaneyulu (2014) and Tok (2010) examined the textbook used in primary schools. While, Rahmawati (2016) and Al Harbi (2017) evaluated the textbooks used in secondary school. Haghi (2013) found that the course books were generally regarded as appropriate materials. While, Salehi (2015) revealed that the content and the topics of the ESP medical textbook are suitable with the learners and instructors' needs.

Lin, et al (2014 found that two dimensions of ESP curriculum model for hospitality field constructed as well as nine courses contained in this study respectively. Also, it appears that Taiwan's hospitality educators and practitioners should assist students/learners to strengthen English proficiency

The previous studies above focused on evaluating the textbooks for general schools such as primary school, for secondary schools and for tertiary school, and however none research which evaluates English textbook used for Vocational High School that recommended used in curriculum 2013. Therefore, the researcher needed to find out the evaluation of English textbook with the research entitled "Evaluation of English Teaching Materials used at a Vocational High School based on Cunningsworth's checklists. (Bahasa Inggris Kelas XI SMA/MA/SMK/MAK, published by Kementerian Pendidikan dan Kebudayaan Republik Indonesia, revised edition in 2017).

The objectives of the research are:

1. To know how the language content in the textbook is viewed from the criteria of good teaching materials

2. To know how the language skills are practiced in the textbook according to criteria of good teaching materials

3. To know how the topics are introduced in the textbook according to criteria of good teaching materials.

Evaluation refers to the process of making judgement based on the criteria or evidence. According to Hutchinson (1983), the evaluation of a textbook assists to the area of English education in two aspects. That is, one aspect is a simple contribution for the teacher in selecting a textbook and the other is that the teacher can increase his own understanding of the teaching and learning situation.

According to Tomlinson (1998; 2001; 2011; 2012), just about everything which helps the learning of a language can be categorized as materials. Materials include everything that can be used to facilitate the language learning. They may be course books, videos, graded readers, flash cards, games, websites or mobile phone interactions. It means textbook is one of materials used by teachers in teaching and learning process.

Dudley-Evans and St John (1998) argue that books and materials have a crucial role in every learning situation and assist teachers with their responsibilities. They provide four justifications for using materials and books: a) as a source of language, b) as a learning support, c) for motivation and stimulation, and d) for reference. 
According to Cunningsworth (1995), materials evaluation is a complex matter, for there are many variables that influence the success or failure of coursebooks when they are in use. So, in evaluating teaching materials, it is essensial to limit the number of aspects used, the number of question asked or statement given, to manageable proportion.

There are some criteria of textbook evaluation proposed by Byrd (2001), Cunningsworth (1995), Littlejohn (1998), Mukundan et, al (2011), Nation and Macalister (2010. In this research, the criteria used adapted from Cunningsworth's checklist.

Cunningsworth (1995: 15-17) mentions four criteria of textbook evaluation. Those criteria as guideline for developing checklist for textbook evaluation. They include 1) corresponding to the learners'needs, 2) reflecting the present and future of language, 3) facilitating learning in various ways, and 4) having a clear role as a support for learning.

Cunningsworth (1995: 3) proposes the most important general criteria for evaluation and selection purposes that called as a basic quick-reference checklist. It covers some aspects. They are a) Aims and approache, b) Design and organization, c) Language content, d) Skills, e) Topics, f) Methodology g) Teachers' books, and h) Practical considerations.

Among eight aspects above, the researcher would like to focus on three aspect only namely language content, skills and topics.

a. Language content

According to Cunningsworth (1995), language content consists of grammar, vocabulary, phonology, and discourse. Grammar is a major component of any general language course, whether it is acknowledged as such, or disguised as something else. It is the effective teaching of grammar that distinguishes a true language course from a phrasebook and it is an understanding of and an ability to use grammar that equips learners with the ability to create their own utterances and use language for their own purposes.

According to Cunningsworth (1995), selecting vocabulary is a hard subject and not as simple as could be hoped. Wilkins (1976) claimed that the attention of methodologists was first directed to vocabulary because the actual day-to-day use of language includes words that are different from the somewhat literary and arbitrary vocabulary that learners encounter in their reading based courses.

Good vocabulary development activities tend to exploit some or all of the following:

- Semantic relation - word group according to meaning, synonyms, hyponyms, opposotes

- Situational relationship - word sets associated with particular situations, eg sport, transport, politics

- Collocations - words commonly found in association, eg food and drink, for better or worse, also noun + preposition links and phrasal verbs (verb + particle links)

- Relationships of form (often referred to as 'word building'), eg long, length, lengthen

Phonology covers the articulation of individual sounds, word stress, sentence stress and some aspects of intonation. Occasionally simple arrows can be employed to denote rising or falling intonation. A cassette recording is the best way of noting stress, rhythm and intonation.

Discourse refers to the features of language use that go beyond the domain of grammar rules and include areas such as the sequencing of sentences, cohesion, paragraphing, structuring text, participation in conversation, etc. Coursebooks will present models of discourse through the examples of language that they offer in dialogue, reading texts, and listening passages. However, we should look for models that 
represent authentic discourse, even though at a simplified level

\section{b. Skills}

The textbook should deal with the four skills (listening, speaking, reading, and writing) that regarded as central to language learning. Teaching English to students means teaching them to comprehend what they read and understand what they listen to. It also means teaching students to express themselves and communicate their thoughts in spoken words and in writing.

c. Topics

Cunningsworth (1995) states it is obvious as using English to deliver information about an aspect of the real world that provides a better model of language use than describe some imaginary non-existent construct, and at the same time is more possibly to motivate the learners. so, another role of the textbook is to include topics that will interest and inform learners. He also emphasizes that at whatever level, real and immediate topics must command more interest and response from learners then imagenary, made-up content.

Learning English in vocational schools is classified as English for Specific Purposes (ESP) and the purpose of learning English is depend on the department/student ${ }^{\text {ee }}$ s major. In line with this , Hutchinson \& Waters (1987) distinguish between "General English" and "ESP". ESP implemented by adapting to the needs of students. Teaching and learning activities are usually focused on student learning as a primary consideration. In other words, teaching ESP implements student centered approach. The needs of students are defined in terms of why they want to learn English and the kind of English that they will use or beneficial to their future.

Cunningsworth (1995) says that ESP materials should meet learners' needs and that the language taught should match the language that the students will use. The materials have to take into account learner expectations and learning styles and should have a clear role in the learning/teaching process.

Dudley-Evans and St John (1998) modified Strevens' original definition of ESP to form their own. Strevens defined ESP by identifying its absolute and variable characteristics. Strevens' (1988) definition makes a distinction between four absolutes and two variable characteristics:

Absolute characteristics:

ESP consists of English language teaching which is:

1. designed to meet specified needs of the learner;

2. related in content (i.e. in its themes and topics) to particular disciplines, occupations and activities;

3. centered on the language appropriate to those activities in syntax, lexis, discourse, semantics, etc., and analysis of this discourse;

4. in contrast with General English. Secondly, variable characteristics: ESP may be, but is not necessarily:

1. restricted as to the language skills to be learned (e.g. reading only);

2. not taught according to any preordained methodology (pp. 1-2).

According to Edwards (2000), when we design a curriculum for ESP courses in the field of ETP (English for Tourism Purposes) learning tasks and activities should have a high surrender value, it means that "learners should be able to use what they have learned to perform their jobs more effectively" ( $p$. 292). Gardner and Walqui (2000) believe that designing a course based on this belief can enhance the learners' inherent motivation which can help and support their learning process. 
Table 1

These are English Materials for Hospitality (Huang, 2008)

\begin{tabular}{|l|ll|}
\hline \multicolumn{2}{|c|}{ Dimensions } & \multicolumn{1}{c|}{ Contents } \\
\hline English for Hotel & 1) & $\begin{array}{l}\text { Reception counter services; check-in registration, introduction to } \\
\text { facilities, luggage service, check-out, cashiei and accounting, tour } \\
\text { pacgkage introductions, lost-and-found services }\end{array}$ \\
& 2) & $\begin{array}{l}\text { Hotel telephone service: room reservation, transfers, taking messages, } \\
\text { telephone manners }\end{array}$ \\
& 3) & Room service: Room administration, complaint response, meal service \\
English for Food & 4) & Other hotel services \\
and Beverage & 2) & Reception counter services \\
Services & 3) & Meal services \\
& 4) & Complaint responses \\
& 5) & Bill payment and see-off services \\
& 6) & Introducing memos \\
& 7) & Introducing utensil and recipes \\
& 8) & Other food and beverage services \\
\hline
\end{tabular}

The proposed language skills and topics that can be applied to students of Hotel and Catering according to Fazelah (2006)

1) Grammar

The learning of grammar should be incorporated into all topics to suit the needs of the students and the industry personnel.

2) Speaking and listening

Speaking and listening skills should be combined because these two skills are done simultaneously in establishing effective communication.

\section{3) Reading}

Hotel accomodation students should be able to read and understand manuals, instruction materials, itinerary, brochures, memos and job specification in English. To assist students in reading skills activities like skimming that is to get gist or general information and scanning that is to locate specifically required information are important in Hotel accomodation. from hospitality journals, magazines and books to encourage quest for knowledge among students.

\section{4) Writing}

Since writing is the least skills preferred by the students and the industry personnel, writing activities would only involve to very specific and job related.

\section{Source: Huang (2008)}

Zarwin (2016) found in his study that speaking and listening skills were maximally needed, reading and writing were minimally needed. The topic for front desk staff was "Making conversation dealing with problems and complaints". The topic of listening was "Listening and practicing dealing with guest situations and complaints. In the topics of reading "Reading about menu". In writing, the most topic needed was "Writing letters, emails, or faxes". It proved that besides general topics, certain topics that concern to the major should be included in Textbook for Vocational High School.

\section{METHODOLOGY Research Design}

This research employed descriptive evaluative design that concerned with the document analysis. This research described whether the aspects of the language content, topic content, and language skills in the textbook entittled Bahasa Inggris Kelas XI SMA/MA/SMK/MAK published by Kementerian Pendidikan dan Kebudayaan Republik Indonesia in 2017 are appropriate to the criteria of good textbook.

\section{Instruments}

The instruments of this research were:

1. Textbook Evaluation checklist

2. Interview 


\section{Data Collection Technique}

In this research, the data were taken from the textbook and collected through content analysis by distributing the checklist to one Vice-principal who also teaches English and two English teachers in a Vocational High School to find out the teachers' responses toward the English textbook used. The researcher and the raters filled the checklist by writing 1 , $2,3,4$, or 5, 1= Absolutely Inappropriate, $2=$ Inppropriate, $3=$ less appropriate , 4= Appropriate, 5= Absolutely Appropriate.

Data Analysis Technique

In analyzing the data obtained, the method used was descriptive. Then the data was analyzed in terms of average. After that, descriptive analysis was employed to obtain a picture of language content, skills, and topics in the textbook used. as follows:

The process of analyzing data done

1. The checklists were counted in each criteria to get the total number

2. Then the total number divided into four to get the its average. The average showed the conditions of materials

3. The checklist of each rater also counted and percentaged

4. The total number of all raters summep up and divided into four to get average

5. Finally, the average of each aspect was percentaged by dividing the average to criteria total number and then multiplied $100 \%$

6. Then, the result was classified into the criteria below:

Table 2

The Conversion of Fulfilment Average into Four Proposed Categories (Pusat Perbukuan, 2011)

\begin{tabular}{|c|c|}
\hline Range of fulfilment score & Category \\
\hline $80 \%-100 \%$ & Good \\
\hline $60 \%-79 \%$ & Fair \\
\hline $50 \%-59 \%$ & Sufficient \\
\hline $0 \%-49 \%$ & Poor \\
\hline
\end{tabular}

\section{RESULT AND DISCUSSION Result}

The findings of this research are presented in three aspects of textbook evaluation. They are language content, skills, and topics.

\section{Language content}

The checklist in this study only covers three items of language content Table 3 namely grammar, vocabulary, and pronunciation. The category covers ten items which are divided into four parts, part A for grammar, part B for vocabulary, part $\mathrm{C}$ for pronunciation, part $\mathrm{D}$ concern to content in general and the results are indicated in table 3

\begin{tabular}{|l|c|l|c|c|c|c|c|c|c|}
\hline \multicolumn{1}{|c|}{ The Result of Textbook Evaluation Checklist } \\
\hline $\begin{array}{c}\text { P } \\
\mathbf{a}\end{array}$ & $\mathbf{N}$ \\
$\mathbf{r}$ & $\mathbf{O}$ & \multicolumn{1}{|c|}{ Statement } & $\begin{array}{c}\text { Rater } \\
\mathbf{1}\end{array}$ & $\begin{array}{c}\text { Rater } \\
\mathbf{2}\end{array}$ & $\begin{array}{c}\text { Rater } \\
\mathbf{3}\end{array}$ & $\begin{array}{c}\text { Rater } \\
\mathbf{4}\end{array}$ & $\begin{array}{c}\text { Total } \\
\text { Num- } \\
\text { ber }\end{array}$ & $\begin{array}{c}\text { Ave- } \\
\text { rage } \\
\text { Score }\end{array}$ & Category \\
\hline $\mathrm{A}$ & 1 & $\begin{array}{l}\text { What grammar items are } \\
\text { included? }\end{array}$ & 3 & 2 & 3 & 3 & 11 & 2.75 & $\begin{array}{c}\text { Less } \\
\text { Appropriate }\end{array}$ \\
\cline { 2 - 9 } & 2 & $\begin{array}{l}\text { The grammar presentation } \\
\text { is clear }\end{array}$ & 3 & 2 & 3 & 3 & 11 & 2,75 & $\begin{array}{c}\text { Less } \\
\text { Appropriate }\end{array}$ \\
\hline
\end{tabular}


Yeli Nurhamsih, Syahrial

\begin{tabular}{|c|c|c|c|c|c|c|c|c|c|}
\hline & 3 & $\begin{array}{l}\text { There are probability, } \\
\text { imperative, polite request, } \\
\text { and conditionals materials }\end{array}$ & 1 & 1 & 2 & 2 & 6 & 1,5 & $\begin{array}{l}\text { Inappro- } \\
\text { priate }\end{array}$ \\
\hline \multirow{3}{*}{ B } & 4 & $\begin{array}{l}\text { How much vocabulary is } \\
\text { taught? }\end{array}$ & 2 & 2 & 1 & 2 & 7 & 1,75 & $\begin{array}{l}\text { Inappro- } \\
\text { priate }\end{array}$ \\
\hline & 5 & $\begin{array}{l}\text { Vocabulary is presented in } \\
\text { structured, purposeful way }\end{array}$ & 2 & 1 & 1 & 2 & 6 & 1,5 & $\begin{array}{l}\text { Inappro- } \\
\text { priate }\end{array}$ \\
\hline & 6 & $\begin{array}{l}\text { Vocabulary introduced in } \\
\text { meaningful context) }\end{array}$ & 1 & 1 & 2 & 1 & 5 & 1,25 & $\begin{array}{l}\text { Absolutely } \\
\text { Inappro- } \\
\text { priate }\end{array}$ \\
\hline $\mathrm{C}$ & 7 & $\begin{array}{l}\text { The coursebook includes } \\
\text { material for pronunciation } \\
\text { work. }\end{array}$ & 1 & 1 & 1 & 1 & 4 & 1 & $\begin{array}{c}\text { Absolutely } \\
\text { Inappro- } \\
\text { priate }\end{array}$ \\
\hline \multirow{3}{*}{$\mathrm{D}$} & 8 & $\begin{array}{l}\text { The coursebook deals with } \\
\text { the how to structure a piece } \\
\text { of extended writing }\end{array}$ & 3 & 1 & 3 & 2 & 9 & 2,25 & $\begin{array}{l}\text { Inappro- } \\
\text { priate }\end{array}$ \\
\hline & 9 & $\begin{array}{l}\text { The content is appropriate } \\
\text { to the learners'need }\end{array}$ & 1 & 1 & 1 & 1 & 4 & 1 & $\begin{array}{l}\text { Absolutely } \\
\text { Inappro- } \\
\text { priate }\end{array}$ \\
\hline & 10 & $\begin{array}{l}\text { There is a body of 'Core' } \\
\text { specialist language }\end{array}$ & 1 & 1 & 1 & 1 & 4 & 1 & $\begin{array}{c}\text { Absolutely } \\
\text { Inappro- } \\
\text { priate }\end{array}$ \\
\hline \multicolumn{3}{|r|}{ TOTAL NUMBER } & 18 & 13 & 18 & 18 & 67 & 14 & \\
\hline \multicolumn{3}{|r|}{ MAXIMAL NUMBER } & 50 & 50 & 50 & 50 & 200 & 50 & \\
\hline \multicolumn{3}{|r|}{ PERCENTAGE } & $36 \%$ & $26 \%$ & $36 \%$ & $36 \%$ & $134 \%$ & $34 \%$ & Poor \\
\hline
\end{tabular}

Table 3 shows that the percentage result of textbook evaluation checklist on language content is $34 \%$. Based on the conversion of fulfilment taken from Pusat Perbukuan, the language content is categorized poor. It means the language contents in the textbook evaluated are not appropriate for Vocational High School specially for Hotel Accomodation Department.

\section{Language Skills}

To evaluate the skills aspect in the textbook, the researcher used ten items. The statements are devided into five parts, part A for integrated skills, part B for listening, part $\mathrm{C}$ for speaking, part $\mathrm{D}$ for reading, and part $\mathrm{E}$ for writing. The results are presented in table 4 below.

Table 4

The Result of Textbook Evaluation Checklist

on Skills

\begin{tabular}{|c|c|c|c|c|c|c|c|c|c|}
\hline $\begin{array}{l}\mathbf{P} \\
\mathbf{a} \\
\mathbf{r} \\
\mathbf{t}\end{array}$ & $\begin{array}{l}\mathbf{N} \\
\mathbf{O}\end{array}$ & Statement & $\begin{array}{c}\text { Rater } \\
1\end{array}$ & $\begin{array}{c}\text { Rater } \\
\mathbf{2}\end{array}$ & $\begin{array}{c}\text { Rater } \\
\mathbf{3}\end{array}$ & $\begin{array}{c}\text { Rater } \\
4\end{array}$ & $\begin{array}{c}\text { Total } \\
\text { Num- } \\
\text { ber }\end{array}$ & $\begin{array}{l}\text { Ave- } \\
\text { rage } \\
\text { Score }\end{array}$ & Category \\
\hline \multirow[b]{2}{*}{ A } & 1 & $\begin{array}{l}\text { The four skills } \\
\text { adequately covered }\end{array}$ & 2 & 1 & 3 & 3 & 9 & 2,25 & Inappro-priate \\
\hline & 2 & $\begin{array}{l}\text { There is material for } \\
\text { integrated skills work }\end{array}$ & 3 & 2 & 3 & 3 & 11 & 2,75 & $\begin{array}{c}\text { Less } \\
\text { Appropriate }\end{array}$ \\
\hline \multirow[t]{2}{*}{ B } & 3 & $\begin{array}{l}\text { The textbook is provided } \\
\text { with the cassette / cd for } \\
\text { listening activity }\end{array}$ & 1 & 1 & 1 & 1 & 4 & 1 & $\begin{array}{l}\text { Absolutely } \\
\text { Inappro-priate }\end{array}$ \\
\hline & 4 & $\begin{array}{l}\text { Listening material is } \\
\text { well recorded. }\end{array}$ & 1 & 1 & 1 & 1 & 4 & 1 & $\begin{array}{c}\text { Absolutely } \\
\text { Inappro-priate }\end{array}$ \\
\hline $\mathrm{C}$ & 5 & $\begin{array}{l}\text { There are sufficient } \\
\text { materials for spoken } \\
\text { English }\end{array}$ & 3 & 3 & 4 & 2 & 12 & 3 & $\begin{array}{l}\text { Less Appro- } \\
\text { priate }\end{array}$ \\
\hline \multirow{3}{*}{$\mathrm{D}$} & 6 & $\begin{array}{l}\text { There are sufficient } \\
\text { reading materials }\end{array}$ & 3 & 3 & 4 & 2 & 12 & 3 & $\begin{array}{c}\text { Less Appro- } \\
\text { priate }\end{array}$ \\
\hline & 7 & \begin{tabular}{llr} 
There are & \multicolumn{2}{r}{ reading } \\
materials & such & as \\
manuals & and & job \\
specification & & \\
\end{tabular} & 1 & 2 & 1 & 1 & 5 & 1,25 & $\begin{array}{l}\text { Absolutely } \\
\text { Inappro-priate }\end{array}$ \\
\hline & 8 & $\begin{array}{l}\text { There are acttivity of } \\
\text { reading for pleasure and } \\
\text { job knowledge }\end{array}$ & 1 & 2 & 1 & 1 & 5 & 1,25 & $\begin{array}{l}\text { Absolutely } \\
\text { Inappro-priate }\end{array}$ \\
\hline
\end{tabular}


Yeli Nurhamsih, Syahrial

\begin{tabular}{|c|c|l|c|c|c|c|c|c|c|}
\hline \multirow{2}{*}{$\mathrm{E}$} & \begin{tabular}{l} 
E \\
\cline { 2 - 10 }
\end{tabular} & $\begin{array}{l}\text { Writing activities are } \\
\text { suitable in term of } \\
\text { length, degree of } \\
\text { accuracy, and amount of } \\
\text { guidance. }\end{array}$ & 2 & 1 & 2 & 3 & 8 & 2 & Inappro-priate \\
\hline $\begin{array}{l}\text { There are varied genre of } \\
\text { writing that include } \\
\text { writing that concern to } \\
\text { job specification }\end{array}$ & 2 & 2 & 1 & 1 & 6 & 1,5 & Inappro-priate \\
\hline TOTAL NUMBER & 19 & 18 & 21 & 18 & 76 & 19 & \\
\hline MAXIMAL NUMBER & 50 & 50 & 50 & 50 & 200 & 50 & Poor \\
\hline
\end{tabular}

The table 4 above shows the percentage result of textbook evaluation checklist for language skills aspect is $38 \%$. Based on conversion of fulfilment proposed by Pusat Perbukuan, the language skills are categorized poor. It indicates that the materials for language skills in the textbook are inappropriate for hotel accomodation department.

\section{Topics}

The checklist evaluated the topic appropriateness of the textbook in statement by including seven criteria as indicated in table 5

The Result of Textbook Evaluation Checklist

on Topics

\begin{tabular}{|c|l|c|c|c|c|c|c|c|}
\hline NO & \multicolumn{1}{|c|}{ Statement } & $\begin{array}{c}\text { Rater } \\
\mathbf{1}\end{array}$ & $\begin{array}{c}\text { Rater } \\
\mathbf{2}\end{array}$ & $\begin{array}{c}\text { Rater } \\
\mathbf{3}\end{array}$ & $\begin{array}{c}\text { Rater } \\
\mathbf{4}\end{array}$ & $\begin{array}{c}\text { Total } \\
\text { Number }\end{array}$ & $\begin{array}{c}\text { Average } \\
\text { Number }\end{array}$ & Category \\
\hline 1 & $\begin{array}{l}\text { There is sufficient material } \\
\text { of genuine interest to } \\
\text { learners }\end{array}$ & 2 & 2 & 3 & 2 & 9 & 2,25 & Inappro-priate \\
\hline 2 & $\begin{array}{l}\text { There are enough variety } \\
\text { and range of topics in the } \\
\text { textbook }\end{array}$ & 2 & 4 & 3 & 2 & 11 & 2,75 & $\begin{array}{c}\text { Less } \\
\text { Appropriate }\end{array}$ \\
\hline 3 & $\begin{array}{l}\text { The topics will help enrich } \\
\text { their experience. }\end{array}$ & 3 & 1 & 2 & 2 & 8 & 2 & Inappropriate \\
\hline 4 & $\begin{array}{l}\text { The topics are current } \\
\text { enough in content }\end{array}$ & 2 & 2 & 3 & 3 & 10 & 2,5 & $\begin{array}{c}\text { Less } \\
\text { Appropriate }\end{array}$ \\
\hline 5 & $\begin{array}{l}\text { The material can be used } \\
\text { for individual study }\end{array}$ & 3 & 2 & 2 & 3 & 10 & 2,5 & Less \\
\hline 6 & $\begin{array}{l}\text { There are topics that } \\
\text { integrated with issues in } \\
\text { hospitality industry }\end{array}$ & 1 & 2 & 2 & 1 & 6 & 1,5 & Inappropriate \\
\hline 7 & $\begin{array}{l}\text { The topics actually do } \\
\text { what they set out to do }\end{array}$ & 3 & 3 & 3 & 3 & 12 & 3 & Less \\
\hline TOTAL NUMBER & 16 & 16 & 18 & 16 & 66 & 16,5 & 35 \\
\hline
\end{tabular}

In table 5 , it shows the percentage result of textbook evaluation checklist for topics is $47 \%$. Based on conversion of fulfilment derived from Pusat Perbukuan, the percentage indicates that the materials concerning to topics are categorized poor. The topics are inappropriate for the students of hotel accomodation.

\section{Research Result from interview}

Based on interview result, the textbook evaluated is not suitable enough specially for Vocational High School so the teachers should add the materials themselves by adding from other textbook/sources or browse from internet. All the materials in the textbook are general English materilas. It showed from respondent answer (R0021 and R0031).

The materials and activities in the textbook were limited. It is lack variety of tasks so the teacher should adapt or add some activities to suit different needs of students. (R0022, R0032, and R0042). They should vary the strategies in teaching and learning too. 
From the interview, it was revealed that the respondents suggested our government (Ministry of Education and Culture) should design spesial syllabus of English for Vocational High School that toward to ESP approach, it should differ syllabus between SMA and SMK and add the time for teaching English from 2 become 4 hours in a week so the teachers can maximize the teaching and learning process of English in classroom. (R0025 and R0035)

\section{Discussion}

\section{Language Content}

The finding shows that the percentage result of textbook evaluation checklist on language content is categorized poor. It means the language contents in the textbook evaluated are not appropriate for Vocational High School specially for Hotel Accomodation Department. The textbook only covers little grammar and vocabulary in general English content where non of the topics is related to hotel accomodation. It is probably because the textbook actually is designed for SMA but it is a pity the textbook also recommended to be used for SMK. As we know, learning English at Vocational High School is classified as English for Specific Purposes (ESP) and the purpose of learning English is depend on department/students' major (Hutchinson \& Waters, 1986, Cunningsworth, 1995). It is because the orientation of the vocational high school known as SMK is to prepare students to be able to take part in the business \& industry work. In learning English, the materials are expected to meet the needs of students in each department. Needs in each of these departments should be covered because English used in speaking and writing differ from one context to another.

\section{Language Skills}

The second result of the research shows the percentage of textbook evaluation checklist for language skills aspect is categorized poor. It indicates the materials for language skills are inappropriate for hotel accomodation department since the materials are general English content and the activities for the skills are limited. They may not fulfil the students'needs of hotel accomodation. It is a requirement that the skills are trained with the materials or content that relate to hospitality in oder to be meaningful for the students.

A textbook should deal with the four skills (listening, speaking, reading, and writing) which are regarded as central to language learning. However, the balance of language skills being taught may be different from that found in general courses. In some cases, there may be a strong emphasis on the written language and oral skills there may be totally ignored:in other cases the material may focus on very specific skills, such as note taking from talk, presentation or lecture (Cunningsworth, 1995). It is similar to Rahman (2015), he states in General English teaching, all fourlanguage skills; listening, reading, speaking, and writing, are stressed equally. However, in ESP it is a need analysis that determines which language skills are most needed by the learners, and the syllabus is designed accordingly. For example, an ESP program might emphasize the development of writing skills in students who are preparing for graduate work in Business Administration. An ESP program might promote the development of spoken skills in students who are studying English in order to become tourist guides.

\section{Topics}

The third result of the study shows the percentage of textbook evaluation checklist on topic is categorized poor. It indicates the topics introduced in the textbook are inappropriate to hotel accomodation students for the topics in the textbook are regarded as general topics. Non of the topics is related to hotel accomodation. One of possible reasons is the textbook especially designed for general English and tends to be used for 
SMA. However, the problem here, it is also recommended to be used for SMK. The general English in the textbook may be also needed for SMK but it should be accompanied and added some materials of English specific purposes.

The approach taken by DudleyEvans and St.John (1998) stress the connection between profesional activity (occupation) and knowlegde of the English language. English for Professional Purposes allows focusing on work-related needs making it an approach to language teaching, not the product or result of language instruction (Hutchinson \& Waters, 1987). It means the topics in ESP should be designed based on the major of the students. If the students'major is hospitality accomodation, the topics related to hotel accomodation should be included. The kinds of job concerning to hospitality should be provided.

The findings of three aspects show that they are poor or inappropriate English teaching materials for hotel accomodation students. Most of them get category under than 3 or 2 even 1 . The result percentage is under $49 \%$ as poor category. Ideally, the textbook should come to absolutely appropriate (5) or appropriate (4) category minimally. So, it can be said that the textbook is appropriate textbook. The percentage result should achive above $50 \%$ - 59\% to get sufficient category, 60\% $79 \%$ as fair category, and $80 \%-100 \%$ as good category.

The emergence of English for Specific Purposes (ESP) teaching movement resulted from the English language needs of the learners for specific purposes in accordance with their professions or job description. He also says that ESP is goal oriented and focused English teaching and learning, designed for the specific learners according to learners' academic and professional needs. The teaching environment, methods and contents used in ESP are not the same as in General English (Rahman, 2015).
An ESP course is therefore developed based on an assessment of purposes and needs and the activities for which English is needed. In designing the materials for ESP, the teachers should consider who will be taught in order to give appropriate materials for them. After that, the first thing must be decided is topics, provide or find the topics relating to the students' major because the topics will influence all aspects of learning English like grammar, vocabulary, and skills as the main or central part in teaching and learning process (Cunningsworth, 1995 \& Hutchinson and Waters, 1987). In this case, hotel accomodation major needs the language or topics of hospitality and tourism .

\section{CONCLUSIONS AND SUGGESTIONS Conclusions}

The first result shows that the quality of language contents in the textbook are poor. It means the language contents in the textbook evaluated are not appropriate for Vocational High School specially for Hotel Accomodation Department. Among three aspects of language content namely grammar, vocabulary, and pronunciation, the textbook only covers little of grammar and vocabulary. They are in general content. yet there is no specific activity for pronunciation work.

The second result shows the language skills practiced in the textbook are poor. It indicates that the materials for language skills in the textbook are inappropriate for hotel accomodation department because they are presented and practiced with general materials. The activities for all four skills are so limited even there is not cassette or CD provided for listening activities.

The third result, in terms of topics content, shows that the topics introduced in the textbook are poor. It indicates that the topics are inappropriate to the students of hotel accomodation. The result showed the topics introduced in the textbook are a 
variety and current enough but they are not concerned to hospitality industry so they are inappropriate for students of hotel accomodation department. It is essensial to include the topics that concern to the hospitality and tourism department especially for hotel accomodation major. It is because subject or topics content will influnce all aspects of learning English like grammar, vocabulary, and skills as the main or central part in teaching and learning process.

\section{Suggestions}

Here are some suggestions concerning the expected improvement of the textbook.

1. The textbook should be accompanied with other teaching learning media (workbook, cassettes, and CD) so that the materials can be as authentic as possible and very useful specially in listening activity.

2. The four skills should be organized effectively and provided according to which language skills are mostly needed. The activities for language skills should be variety and integrated work.

3. Some writing activities should be modified and familiarized to students'levels

4. The textbook should be provided the functional grammar such as probability, imperative, polite request, and conditionals.

5. The most important things that the textbook should be provided and added the topics content that relate to hospitality and tourism department specially for hotel accomodation department so it will be meaningful for the learners.

This study also suggests Kementrian Pendidikan dan Kebudayaan in this case syllabus designers to design syllabus using ESP aproach for Vocational High School and to develop a new textbook accordingly specially for Hotel Accomodation Department. It is hoped that it will be meaningful materials for the students. Another suggestion, based on the researcher's experience that it is needed to add the time hour for teaching English in Vocational High School from two become four hours in a week, in current curriculum the time hour for teaching English is only two hours, so the teachers can maximize the time to give English for Specific Purpose (ESP).

Another suggestion is given to the future researchers who want to conduct studies on topic of the textbook evaluation. The researcher expects this study can be a reference for future researchers who conduct similar studies.

\section{REFERENCES}

Anjaneyulu, T (2014). A critical analysis of the English language textbooks in Andhra Pradesh, India. International Association of Research in Foreign Language Education and Applied Linguistics ELT Research Journal 2014, 3(4), 181-200 ISSN: 2146-9814 http://www.eltrj.com

Byrd, P. (2001) Textbooks: Evaluation for Selection and analysis for implementation. In Celce-Murcia, M. Teaching English as a second or foreign language (3rd ed). US: Heinle \& Heinle

Chang, W. Y. (2009). A needs analysis of applying an ESP program for hotel employees. Yu Da Academic Journal, 21, 1-16.

Charalambous, A. C. (2011). The Role and Use of Course Books in EFL. (Master's thesis in ELT), Retrieved from http://files.eric.ed.gov/fulltext/ED52424 7.pdf

Cunningsworth, A. (1995). Choosing your coursebook. London: Macmillan Heinemann.

Dudley-Evans, T., \& St. John, A. M. J. (1998). Developments in English for specific purposes: A multi-disciplinary approach. Cambridge: Cambridge University Press.

Edwards, N. (2000). Language for business: Effective needs assessment, syllabus design and materials preparation in a practical ESP case study. English for Specific Purposes, 19(3),291-296

Ellis, R. (1997). The empirical evaluation of language teaching materials. ELT Journal, 51, 36-42. 
Fazelah, S N, (2006) Language Needs For Hotel And Catering Students: A Proposal For Syllabus Design University Tun Hussein Onn Malaysia . Johor, Malaysia

Haghi, E.B (2013). Evaluation Of English

Results Course Books At Upper- Intermediate Level. M.A, Student of

TEFL, University of Guilan, Rasht, Iran.

i-manager's Journal on

English

Language Teaching, Vol. 3 l No. 3 l

July

- September 2013

Huang, C. S. (2008). English

Curriculum Planning for Hospitality.

Proceedings of 2008 International

Conference of Applied Foreign

Languages, 138-140.

Hutchinson, T., \& Waters, A. (1987).

Englishfor specific purposes: A learning-centered approach.

Cambridge.

Lin, C.Y et, al (2014). The Study on

Constructing a Curriculum Model of

Hotel English for Undergraduate

Hospitality Management in Taiwan.

ISSN 1799-2591 Theory and

Practice in Language Studies, Vol.

4, No. 10, pp.

2001-2007, October 2014 @ 2014

ACADEMY PUBLISHER

Manufactured in Finland.

doi:10.4304/tpls.4.10.2001-

2007

Mukundan, J. , Nimehchisalem, V, \& Hajimohammadi, R (2011). Developing

an English Language Textbook Evaluation Checklist: A Focus Group Study. International Journal of

Humanities and Social Science

Vol. 1

No. 12; September 2011

Nation, I. S. P., \& Macalister, J. (2010). Language Curriculum Design. New York: Routledge
Nunan, D. (2003). Practical english

language

Teaching. Singapore:McGraw Hill

Lee, Sun-Min. (2013). The development of evaluation theories for foreign language textbooks. Journal of PanPacific Association of Applied Linguistics, 17(2), 69-89.

Rahman, Momtazur (2015). English for Specific Purposes (ESP): A Holistic Review. Universal Journal of Educational Research 3(1): 24-31, $2015 \quad$ http://www.hrpub.org DOI:

10.13189/ujer.2015.030104.

Copyright

(C) 2015 Horizon Research

Publishing

All rights reserved 
Salehi, et al (2015). An Evaluating Study on ESP Medical Textbook: Instructors and Learners' Needs Analysis. English Language Teaching; Vol. 8, No. 8; 2015

ISSN 1916-4742 E-ISSN 19164750

Published by Canadian Center of

Science and Education

Sheldon, L. E. (1988). Evaluating ELT

textbooks and materials. ELT Journal, 42 ,

246.

https://doi.org/10.1093/elt/42.4.237

Strevens P. (1988). Teaching English as an international language. Oxford: Pergamon Press Ltd;

Tsao, C. H. (2011). English for specific purposes in the EFL context: A survey of student and faculty perceptions. Asian ESP Journal, 7(2), 126-149.

Tok, H. (2010). TEFL textbook evaluation:

From teachers' perspectives.

Educational Research and Review, $5(9)$,

508-517.

Tomlinson, B. (2012). Materials Development for Language Learning \& Teaching.

Language Teaching, 45(2), 143-

179. Zarwin, (2016), An Analysis of Needs in the

Use of English for Specific Purposes (ESP) of the front Desk Staff Hotels in Bengkulu City. Postgraduate Program of English Education Thesis. Department of teaching and Art. Faculty of Teacher Training and Education. Bengkulu University 